\title{
Relations between fish abundances, summer temperatures, and forest harvest in a northern Minnesota stream system from 1997 to 2007
}

Merten EC, Hemstad NA, Eggert SL, Johnson LB, Kolka RK, Newman RM, Vondracek B. Relations between fish abundances, summer temperatures, and forest harvest in a northern Minnesota stream system from 1997 to 2007 .

Ecology of Freshwater Fish 2010: 19: 63-73. (C) 2009 John Wiley \& Sons $\mathrm{A} / \mathrm{S}$

Abstract - Short-term effects of forest harvest on fish habitat have been well documented, including sediment inputs, leaf litter reductions, and stream warming. However, few studies have considered changes in local climate when examining postlogging changes in fish communities. To address this need, we examined fish abundances between 1997 and 2007 in a basin in a northern hardwood forest. Streams in the basin were subjected to experimental riparian forest harvest in fall 1997 . We noted a significant decrease for fish index of biotic integrity and abundance of Salvelinus fontinalis and Phoxinus eos over the study period. However, for P. eos and Culaea inconstans, the temporal patterns in abundances were related more to summer air temperatures than to fine sediment or spring precipitation when examined using multiple regressions. Univariate regressions suggested that summer air temperatures influenced temporal patterns in fish communities more than fine sediment or spring precipitation.

\section{Introduction}

Forest harvest can affect fish populations in streams through a variety of mechanisms. Forest harvest has been related to increased stream discharge, increased inputs of fine sediment, decreased inputs of leaf litter and wood, and community shifts in invertebrates and other biota (Salo \& Cundy 1987; Chamberlin et al. 1991; Palik et al. 2000). Forest harvest can also cause warmer stream temperatures in summer (Hall \& Lantz 1969; Brown 1970; Beschta et al. 1987; DeGroot et al. 2007). Warmer temperatures can lead to changes

\section{E. C. Merten ${ }^{1}$, N. A. Hemstad ${ }^{2}$, S. L. Eggert ${ }^{3}$, L. B. Johnson ${ }^{4}$, R. K. Kolka ${ }^{3}$, R. M. Newman ${ }^{5}$, B. Vondracek ${ }^{6, *}$}

${ }^{1}$ Department of Fisheries, Wildlife, and Conservation Biology and the Water Resources Science Graduate Program, University of Minnesota, St. Paul, MN, USA, ${ }^{2}$ Department of Biology, Inver Hills Community College, Inver Grove Heights, MN, USA, ${ }^{3}$ USDA Forest Service, Northern Research Station, Grand Rapids, MN, USA, ${ }^{4}$ Natural Resources Research Institute, University of Minnesota Duluth, Duluth, MN, USA, ${ }^{5}$ Department of Fisheries, Wildlife, and Conservation Biology, University of Minnesota, St. Paul, MN, USA, ${ }^{6}$ USGS, Minnesota Cooperative Fish and Wildlife Research Unit, University of Minnesota, St. Paul, MN, USA

Key words: Forest harvest; temperature; stream warming; basin scale

Eric C. Merten, Department of Fisheries, Wildlife, and Conservation Biology, University of Minnesota, 1980 Folwell Ave, St. Paul, MN 55108, USA; e-mail: mert0042@umn.edu

${ }^{*}$ The Unit is jointly sponsored by the U.S. Geological Survey, the University of Minnesota, the Minnesota Department of Natural Resources, the Wildlife Management Institute, and the U.S. Fish and Wildlife Service.

Accepted for publication September 18, 2009 in growth rates for fish and invertebrates (Weatherley \& Ormerod 1990) and alter the competitive balance between species (Baltz et al. 1982; Reeves 1985). Although warming effects from forest harvest may be masked by variability in air temperatures (Eaton \& Scheller 1996; Pilgrim et al. 1998), warming from any cause is of obvious importance to aquatic ectotherms, particularly in light of ongoing climate change (Austin \& Colman 2008; Rosenzweig et al. 2008).

The effects of forest harvest may be detected most readily at the basin scale (Hemstad \& Newman 2006; Martel et al. 2007), particularly in basins that corre- 


\section{Merten et al.}

spond to the spatial scale of fish life cycles (Fausch et al. 2002). Although many studies have examined site-level effects of forest harvest (Broadmeadow \& Nisbet 2004), few have examined multiple streams across multiple years (DeGroot et al. 2007). Williams et al. (2002) determined in the Ouachita Mountains that instream habitat varied by basin, year, logging treatment, and basin/treatment interaction; macroinvertebrates varied by year and basin, but basin was the only significant factor for fish. By filtering out natural spatial variability, Martel et al. (2007) detected reductions in long-lived, large invertebrates when $<1 \%$ of the area of basins were clearcut in Quebec, Canada. However, temporal replication for both studies was limited to two or three years of sampling (Williams et al. 2002; Martel et al. 2007).

When examined at the basin scale, stream hydrology may be strongly affected by forest harvest (Salo \& Cundy 1987; Chamberlin et al. 1991). For example, peak snowmelt discharge increased relative to unharvested watersheds for at least five years postharvest in British Columbia, Canada (Macdonald et al. 2003). Increases in snowmelt discharge may persist for 15 years postharvest in hardwood forests of the north-central USA (Verry 1986). Moore \& Wondzell (2005) provide a review of effects of forest harvest on hydrology, confirming that recovery takes place on a decadal time scale. A more flashy hydrograph following forest harvesting can have direct effects on fish assemblages by favouring some species over others (Poff \& Allen 1995), and can also increase turbidity and sediment loading in streams. Serengil et al. (2007a) noted that thinning only $11 \%$ of the standing timber volume with horse skidding produced a detectable increase in streamflow during the rainy season in Turkey, as well as a significant increase in suspended sediment (Serengil et al. 2007b). Forested land cover can affect not only turbidity, but also bedload, embeddedness, and channel stability (Sutherland et al. 2002).

Sediment in streams can have deleterious effects on stream invertebrates and fish (Waters 1995). Matthaei et al. (2006) added sediment directly to agricultural streams that were degraded from past land use, and found reduced densities for some common macroinvertebrate taxa. Their experimental approach was reminiscent of Alexander \& Hansen (1986), who conducted experimental sediment additions and documented lower trout numbers due to reduced egg-to-fingerling survival. Juvenile salmon prefer interstitial spaces that are relatively free of sediment (Finstad et al. 2007).

Forest harvest can also affect supplies of wood and leaf litter to streams. Wood inputs may exhibit a longterm reduction after forest harvest (Murphy \& Koski 1989), which may reduce available habitat for macr- oinvertebrates (Johnson et al. 2003) and fish (Crook \& Robertson 1999). Natural levels of large wood have tremendous ecological value as providers of habitat and shapers of geomorphology (Angermeier \& Karr 1984; Beechie \& Sibley 1997; Quist \& Guy 2001; Johnson et al. 2003; Borg et al. 2007). Large wood also increases retention of leaf litter (Ehrman \& Lamberti 1992; Larranaga et al. 2003; Quinn et al. 2007); even if large wood is unchanged forest harvest can directly reduce leaf litter inputs (Oelbermann \& Gordon 2000; Kreutzweiser et al. 2004). In the Pokegama Creek system in north-central USA, litter inputs were significantly reduced after riparian harvest, despite a 30-m riparian buffer (Palik et al. 2000). In addition, forest harvest can lead to increases in light levels, periphyton, and macrophytes (Kedzierski \& Smock 2001; Kiffney et al. 2003; Davies et al. 2005), and may induce changes in fish communities (Bojsen \& Barriga 2002; Nislow \& Lowe 2006).

The objective of the current study was to examine changes in fish abundances in the Pokegama Creek system, Minnesota, USA over an 11-year time frame in light of experimental forest harvest, habitat conditions, and variation in local climate. Previous studies in the Pokegama Creek system examined effects for three years postharvest on fish and habitat (Hemstad et al. 2008) and leaf litter inputs (Palik et al. 2000). Although few significant treatment effects were observed at the site level in the first few years after harvest (Hemstad et al. 2008), a longer temporal scale and broader spatial scale may be more appropriate (Fausch et al. 2002). We collected new data nine and ten years postharvest to examine longer-term temporal patterns in the fish community at the basin scale. We also used local weather data to determine the influence of summer air temperature and amount of spring precipitation on fish abundances.

\section{Methods}

\section{Study area and sites}

The study was conducted on four headwater streams in the Pokegama Creek system, south of Grand Rapids in north-central Minnesota (Fig. 1). The streams flow into Pokegama Lake. The basin was forested and dominated by northern hardwoods (Palik et al. 2003). Prior to the study the mean basal area of forest stands was $30 \mathrm{~m}^{2} \cdot \mathrm{ha}^{-1}$ (Palik et al. 2003). Topography included moraine hills rising $\sim 5 \mathrm{~m}$ above the valley floor, with hillslopes of 1-30\% (unpubl. data). Bankfull widths at the study sites were $\sim 2 \mathrm{~m}$ and stream slopes were $0.7-3.5 \%$. Soils were generally fertile with well-drained loamy sands (Palik et al. 2003), including occasional gravel lenses and cobble/boulder inclusions. 
Fig. 1. Study sites located near Grand Rapids, MN, USA. Each site is 4.9 ha. Sampling reaches are shown at two hypothetical sites at bottom (not to scale). $\mathrm{RMZ}=30 \mathrm{~m}$ wide riparian management zone.

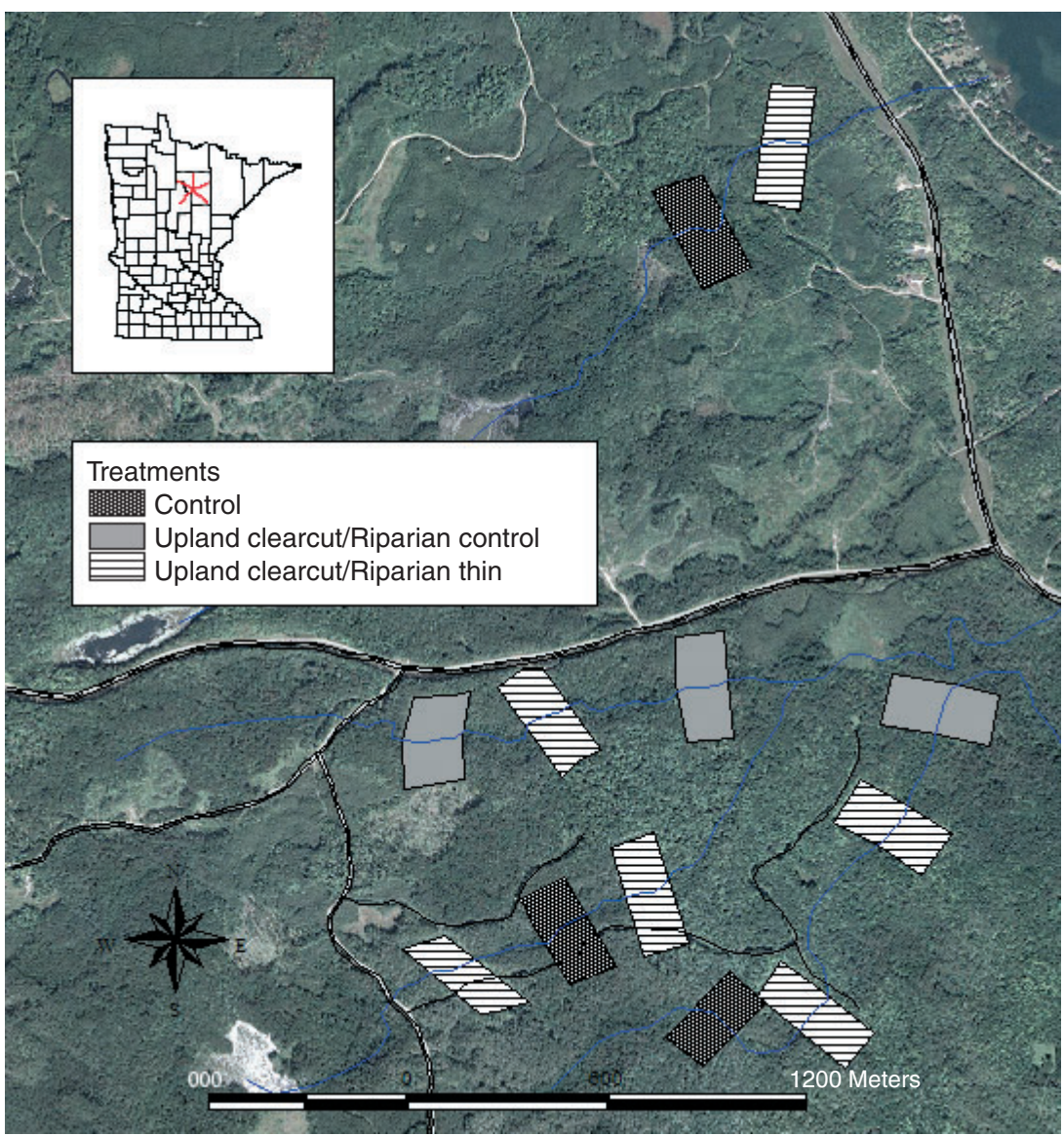

In 1997, 12 study sites were established along the four headwater streams, although one site became dry each summer and was thus excluded from analyses (Fig. 1). The 11 remaining sites were each about 4.9 ha, with 2.45 ha on each side of the stream; sites were generally $\sim 200 \mathrm{~m}$ apart. Each site included 150 $200 \mathrm{~m}$ of stream length. Harvest treatments at each site were either unharvested control $(N=2)$, upland clearcut with 30-m unharvested buffers (riparian buffer, $N=3$ ), or upland clearcut with 30-m riparian strips thinned to $12.3 \mathrm{~m}^{2} \cdot \mathrm{ha}^{-1}$ basal area (thinned riparian, $N=6$ ). All forest harvests were conducted in fall and winter of 1997. The total harvested areas represented $2-11 \%$ of the four catchments, which is near the lower threshold for harvest effects in prior studies (Martel et al. 2007; Serengil et al. 2007a,b). As suggested by analyses using data from 1997 to 2000 (Hemstad et al. 2008), the current study investigated changes and relationships at the basin scale. Thus, the following analyses did not differentiate between harvest treatments at the site scale, with the exception of the site-level analysis of stream warming.

\section{Data collection}

Fish were sampled during August in 1997 (preharvest), 1998-2000, and 2006-2007. Fish were sampled in three $50-\mathrm{m}$ reaches at each site; $50 \mathrm{~m}$ immediately upstream of the site, the lowermost $50 \mathrm{~m}$ of the site, and $50 \mathrm{~m}$ immediately downstream of the site (Fig. 1). All sampling was conducted with a Wisconsin AbP-3 backpack electrofisher (Engineering Technical Services, University of Wisconsin, Madison, Wisconsin). A coldwater fish index of biotic integrity (IBI) value was calculated for each 50-m reach (Mundahl \& Simon 1999). The IBI increases with the proportion of species that are ranked as intolerant, top carnivores, and coldwater obligates [e.g., brook trout (Salvelinus fontinalis)] and decreases with the proportion of tolerant species [e.g., central mudminnow (Umbra limi, Kirtland) or creek chub (Semotilus atromaculatus, Mitchill)]. Brook trout comprised $>99 \%$ of the individuals in the southern streams (Fig. 1) and were absent from the other streams, thus brook trout analyses only used data from the southern stream. Analyses for other individual species only used data from the three northern streams, and the IBI analyses used data from all four streams.

Abundance estimates were calculated for each species in each 50-m reach. During the first pass, fish were electrofished from the $50 \mathrm{-m}$ reach, identified to species, and marked with a caudal fin clip. The fish were then redistributed throughout the reach. Approximately an hour after the first pass, a second electro- 


\section{Merten et al.}

fishing pass was completed through the reach. Fish captured during the second pass were identified to species, and checked for a fin clip. This method allowed calculation of an abundance estimate for each species using both a depletion method and a markrecapture method (PopPro; Kwak 1992). If catchability (Kwak 1992) for a species was $\geq 0.8$, the depletion method was used. If catchability was $<0.8$, but the ratio of recaptured fish to total second-pass fish ( $\mathrm{r} / \mathrm{c}$ ratio) was $>0.2$, the mark-recapture method was used. If catchability was $0.5-0.8$ or the $\mathrm{r} / \mathrm{c}$ ratio was $0.15-$ 0.2 , the method toward the higher end of its range was used. When catchability was $<0.5$ and the $\mathrm{r} / \mathrm{c}$ ratio was $<0.15$, the sum of captures for the first and second pass was used; the sum never exceeded ten fish in such cases.

Surficial fine substrates were examined in July 1997-2000 and 2006-2007 as an indicator of habitat for fish and invertebrates (Hemstad et al. 2008). Each 50-m reach was divided into five equal subreaches, to avoid sampling exclusively at the upstream or downstream end of a $50-\mathrm{m}$ reach. Seven circular quadrats (28 cm in diameter) were assessed in random locations in each $10-\mathrm{m}$ subreach to visually estimate the areal percentage of the substrate that was sand, silt, or clay (i.e., fine substrates). Thus, we sampled 7 quadrats $\times 165$ subreaches to equal 1155 quadrats per year.

Basin-scale relations between temporal patterns in fish and environmental variables were examined using the mean from all sites in the Pokegama Creek system each year. Univariate regressions were used to investigate temporal trends for the basin means for fish index of biotic integrity and abundances, and to investigate relationships between fish and fine sediment at the basin scale. Univariate regressions were also used to examine the relationships between fish variables and two climate variables. The first climate variable was summer air temperature, using the mean air temperature from June through August of each year at the nearest monitoring station $10 \mathrm{~km}$ to the north (Minnesota State Climatology Office). The second climate variable was total spring precipitation, the cumulative precipitation from April 1 through July 12 (prior to field sampling) of each year. The proportion that each fish species contributed to total fish abundance was also examined with a rank abundance curve for each year sampled.

Temporal patterns in fish variables were examined further with multiple regressions, using surficial fine substrates, summer air temperature, and total spring precipitation as predictor variables. The final regression model was chosen using the stepAIC function of the statistical software $\mathrm{R}$ to determine the model with the fewest predictors that would each make a significant improvement to the AIC (Weisberg 1985).
Site-level effects on stream temperature were examined in 2006 and 2007 during August (the warmest month). An Onset ${ }^{\circledR}$ Pro v2 temperature recorder (Onset, Pocasset, MA, USA) was placed $0-50 \mathrm{~m}$ upstream and another was placed $0-50 \mathrm{~m}$ downstream of each site. Each recorder (Onset, Pocasset, MA, USA) was cabled to a brick in the deepest pool available and was set to measure water temperature every $15 \mathrm{~min}$. The response variable examined for water temperature was the mean temperature in August for the downstream recorder minus the mean temperature in August for the upstream recorder (i.e., sitelevel warming). Of the 24 recorders set each year, two became exposed to air due to low water levels, one was buried by bedload, and one was vandalized; the corresponding sites were omitted from the site-level analysis. A two-factor ANOvA was used to evaluate site-level warming, using the software R (Ihaka \& Gentleman 1996). The first factor for the ANOVA was year (2006 vs. 2007) and the second factor was treatment (unharvested control, riparian buffer, or thinned riparian). No transformations were necessary; Tukey's HSD was used to compare mean values.

\section{Results}

The IBI scores decreased significantly over time (Table 1), as did mean abundance for brook trout and northern redbelly dace (Phoxinus eos, Cope, Table 1). Mean abundance of brook stickleback (Culaea inconstans, Kirtland) also decreased over time while creek chubs increased, although neither trend was significant $(r=-0.70$ and $0.79, P=0.12$ and 0.06). Central mudminnow and finesecale dace (Phoxinus neogaeus, Cope) showed no trend. Other species [i.e., emerald shiner (Notropis atherinoides, Rafinesque), fathead minnow (Pimephales promelas, Rafinesque), Iowa darter (Etheostoma exile, Girard), and northern pike (Esox lucius, Linnaeus)] were uncommon (Table 1) and were not included in species-level analyses. In terms of relative abundances, brook trout were the most abundant species from 1997 through 1999 but declined to fourth and third most abundant by 2006 and 2007. Central mudminnows were fourth or fifth most abundant from 1997 through 2000 and became the most abundant species in 2006 and 2007 (Fig. 2).

Some changes occurred with fine sediment and local weather. Fine substrates increased after 1997 and total spring precipitation increased from 1997 through 1999 and subsequently decreased (Table 2). On average, summer air temperatures increased over the study period by $0.062{ }^{\circ} \mathrm{C} \cdot$ year $^{-1}$ at the nearest weather station (Fig. 3), which is comparable to the regional trend of $0.06{ }^{\circ} \mathrm{C} \cdot$ year $^{-1}$ (Austin \& Colman 2008).

The multiple regressions for brook stickleback abundance and northern redbelly dace abundance were 
Relations between fish abundances, summer temperatures, and forest harvest

Table 1. Yearly average IBI score and mean number of fish by species per 50-m reach, based on calculated abundance estimates.

\begin{tabular}{|c|c|c|c|c|c|c|c|c|}
\hline & 1997 & 1998 & 1999 & 2000 & 2006 & 2007 & $r$ & $P$ \\
\hline IBI score & $57.78(5.84)$ & $55.56(5.54)$ & $62.92(5.19)$ & $59.86(5.71)$ & $39.44(5.16)$ & $39.31(6.24)$ & -0.91 & 0.01 \\
\hline Brook trout & $13.34(5.29)$ & $12.77(4.16)$ & $10.16(3.57)$ & $8.84(2.31)$ & $1.03(0.55)$ & $1.83(0.79)$ & -0.99 & 0 \\
\hline Northern redbelly dace & $4.8(2.15)$ & $3.85(2.21)$ & $2.41(0.84)$ & $5.23(2.32)$ & $0.89(0.37)$ & $0.36(0.19)$ & -0.86 & 0.03 \\
\hline Brook stickleback & $10.69(4.93)$ & $11.35(2.86)$ & $1.92(0.6)$ & $8.78(2.87)$ & $2.19(0.81)$ & $3.19(1.88)$ & -0.7 & 0.12 \\
\hline Creek chub & $0.06(0.06)$ & $0.71(0.33)$ & $0.14(0.09)$ & $1.02(0.39)$ & $0.86(0.29)$ & $1.83(0.94)$ & 0.79 & 0.06 \\
\hline Central mudminnow & $4.74(1.26)$ & $7.57(1.44)$ & $1.75(0.55)$ & $3.74(0.87)$ & $5.39(1.35)$ & $3.42(1.22)$ & -0.14 & 0.79 \\
\hline Finescale dace & $0.16(0.16)$ & $5.57(2.01)$ & $2.09(0.79)$ & 19.11 (8.38) & $1.83(0.78)$ & $1.22(0.44)$ & -0.19 & 0.72 \\
\hline Fathead minnow & $0(0)$ & $11.34(4.04)$ & $1.01(0.45)$ & $0.53(0.51)$ & $0(0)$ & $0(0)$ & * & * \\
\hline Iowa darter & $0(0)$ & $0(0)$ & $0.03(0.03)$ & $0(0)$ & $0(0)$ & $0(0)$ & * & * \\
\hline Northern pike & $0(0)$ & $0(0)$ & $0(0)$ & $0(0)$ & $0(0)$ & $0.03(0.03)$ & * & * \\
\hline Emerald shiner & $0(0)$ & $0(0)$ & $0.03(0.03)$ & $0(0)$ & $0(0)$ & $0(0)$ & * & * \\
\hline
\end{tabular}

Standard errors of the mean are in parentheses. The Pearson correlation coefficient $(r)$ and $P$-value $(P)$ are for the regression with year.

*Species was too rare.

significant and marginally significant, respectively (Table 3). Higher abundances of both species were associated with years with colder summer air temperatures, and surficial fine substrates or total spring rainfall were excluded by the AIC procedure. Multiple regressions were not significant for any other species.

In univariate regressions, temporal patterns in IBI scores and abundances for brook trout, northern redbelly dace, and brook stickleback (Fig. 4) were
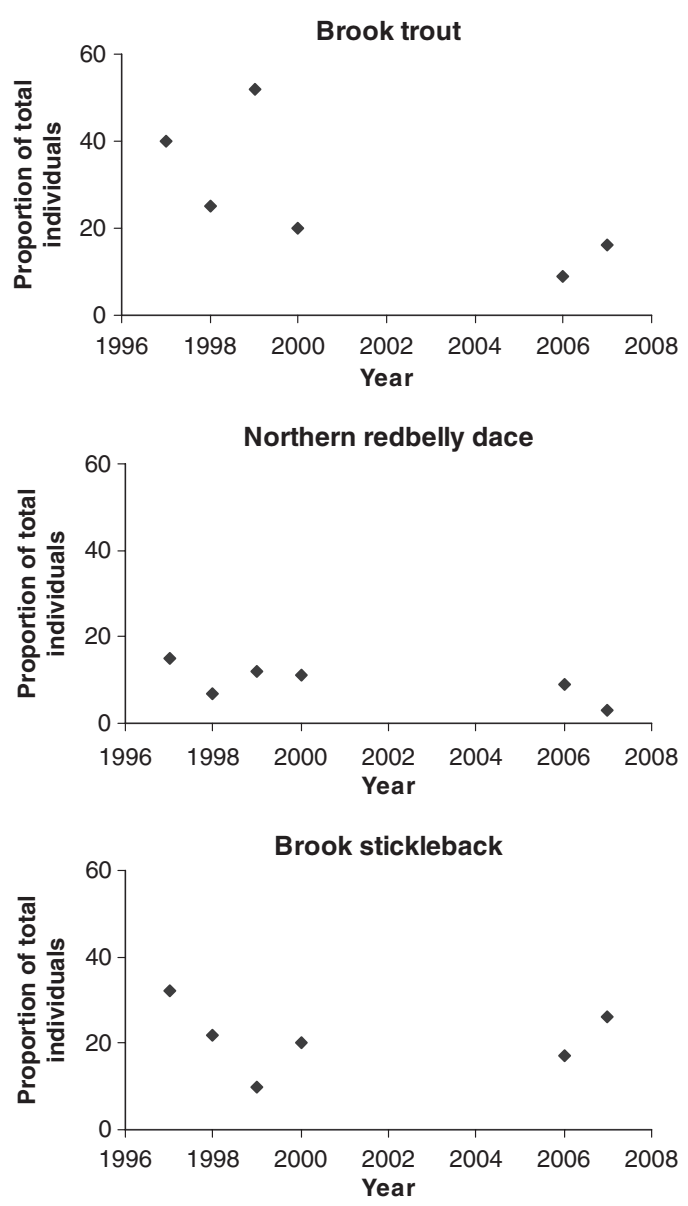

Fig. 2. Changes in proportion of total individuals across all sites. negatively related to warmer summer air temperatures; finescale dace also had a similar marginal relation $\left(r^{2}=0.49\right.$, not shown $)$. Univariate regressions showed no relations between temporal patterns in fish index of biotic integrity or abundances with fine sediment or spring precipitation (Table 4).

There were significant site-level treatment effects on stream warming for 2006 and 2007 (i.e., downstreamupstream differences in water temperature, Fig. 5).
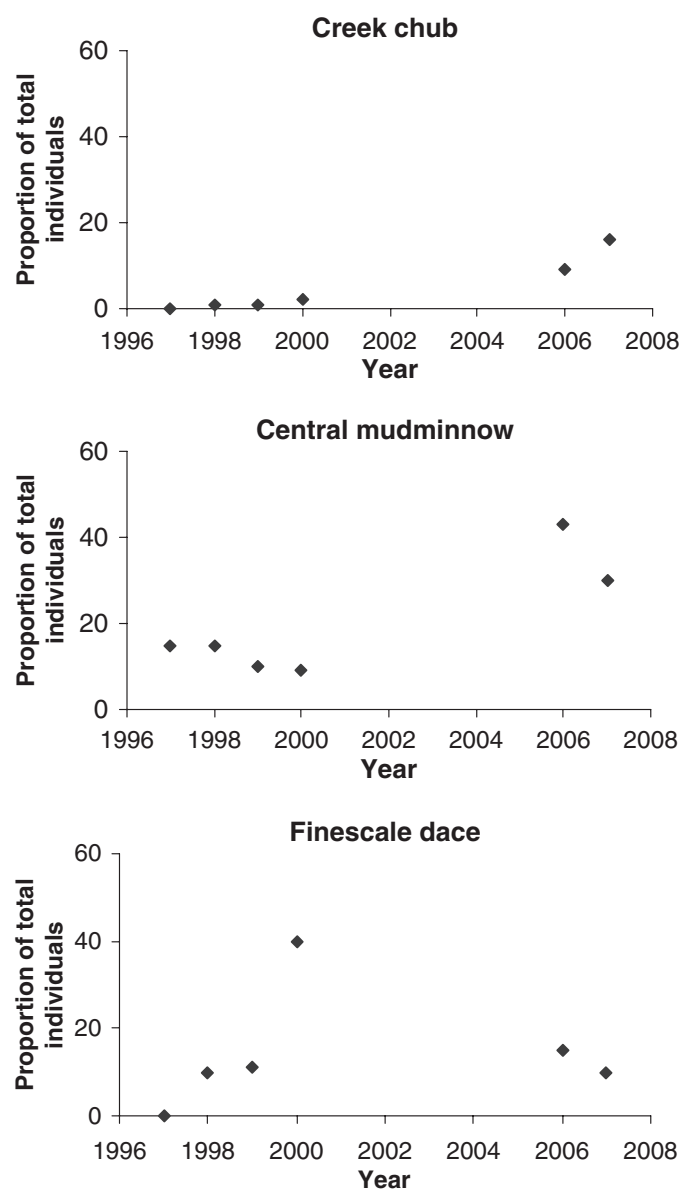


\section{Merten et al.}

Table 2. Yearly average values for all reaches for the proportion of fine substrates and total spring precipitation.

\begin{tabular}{lllllrr}
\hline & 1997 & 1998 & 1999 & 2000 & 2006 & 2007 \\
\hline Fine substrates (\%) & $53.6(3.4)$ & $69.2(1.9)$ & $60.9(2.9)$ & $62.6(2.6)$ & $67.2(4.1)$ & $60.8(3.1)$ \\
Total spring precipitation (mm) & 274 & 388 & 404 & 260 & 247 & 231 \\
\hline
\end{tabular}

Standard errors of the mean are in parentheses.

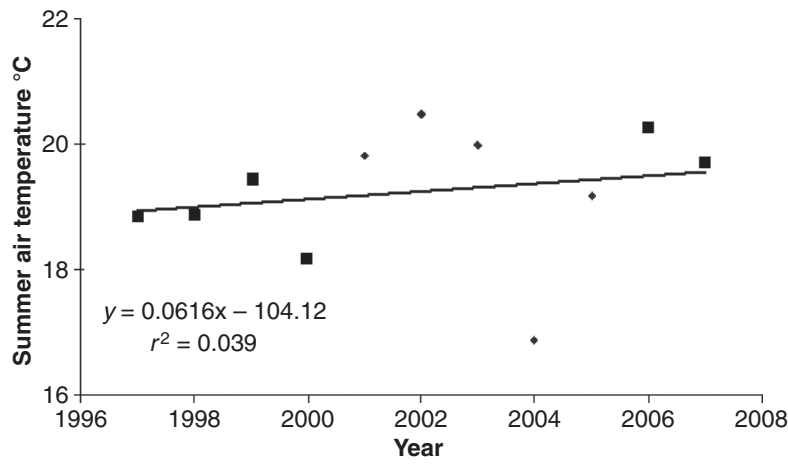

Fig. 3. Mean summer air temperatures for June through August 1997 through 2007. Boxes denote years during which fish were sampled.

Table 3. $P$-values for predictor variables in multiple regressions for $\mid \mathrm{BI}$ scores and fish abundances.

\begin{tabular}{llll}
\hline & $\begin{array}{l}\text { Fine } \\
\text { substrates } \\
(\%)\end{array}$ & $\begin{array}{l}\text { Summer air } \\
\text { temperature } \\
\left({ }^{\circ} \mathrm{C}\right)\end{array}$ & $\begin{array}{l}\text { Total spring } \\
\text { precipitation } \\
(\mathrm{mm})\end{array}$ \\
\hline $\begin{array}{l}\text { Index of biotic integrity } \\
\mathbf{0 . 7 7}(0.135)\end{array}$ & NA & NA & NA \\
$\begin{array}{l}\text { Brook trout } \\
\mathbf{0 . 6 9}(0.179)\end{array}$ & NA & NA & NA \\
$\begin{array}{l}\text { Northern redbelly dace } \\
\mathbf{0 . 8 1}(0.009)\end{array}$ & NA & 0.009 & NA \\
$\begin{array}{l}\text { Brook stickleback } \\
\mathbf{0 . 5 2}(0.064)\end{array}$ & NA & 0.064 & NA \\
$\begin{array}{l}\text { Creek chub } \\
\mathbf{0 . 2 5}(0.300) \\
\text { Central mudminnow }\end{array}$ & NA & NA & NA \\
$\mathbf{0 . 6 5}(0.801)$ & NA & NA & NA \\
$\begin{array}{l}\text { Finescale dace } \\
\mathbf{0 . 4 8}(0.293)\end{array}$ & NA & NA & NA \\
\hline
\end{tabular}

Adjusted $r^{2}$ for the multiple regression model is in bold, $P$-value is in parentheses.

NA $=$ Overall $P$-value for model was not significant.

The ANOvA for site-level warming showed that the year factor was not significant $(P=0.65)$, but the treatment factor was significant $(P=0.02)$. Tukey's HSD comparison indicated that warming was significantly greater $(P=0.01)$ in thinned riparian sites compared to riparian buffer sites. However, warming at the unharvested control sites was not significantly different from the riparian buffer sites or the thinned riparian sites $(P>0.17)$ for 2006 and 2007.

\section{Discussion}

We found that temporal patterns in abundances of brook stickleback and northern redbelly dace were significantly related to summer air temperatures at the basin scale. In addition, univariate regressions showed relations between summer air temperatures and IBI scores, brook trout abundance, and finescale dace abundance. Conversely, no fish variables were related to temporal patterns in fine sediment or total spring precipitation. Below we discuss overall changes in the fish community, followed by discussion of changes in abundance for common species.

The spatial scale of the Pokegama Creek system likely encompassed the life cycles of the fish species (Fausch et al. 2002). Brook trout were only sampled in one stream, and would need to migrate $5 \mathrm{~km}$ through a warmwater river to reach the nearest coldwater stream outside the study area. The other small-bodied species were considered likely to have spent their entire life cycles within the headwater stream system. IBI scores showed a significant negative trend over the study period, and abundances of sensitive species [i.e., brook trout, northern redbelly dace (Stasiak 1972), and brook stickleback (Winn 1960)] also appeared to decline. Meanwhile, the abundance of tolerant creek chubs increased.

Overall fish numbers were markedly lower in 2006 and 2007. There are several possible explanations for the decline. First, diminished leaf litter inputs after forest harvest (Palik et al. 2000) may have led to bottom-up trophic effects, as could decreased retention of leaf litter due to less large wood in the channels (Ehrman \& Lamberti 1992; Larranaga et al. 2003; Quinn et al. 2007). Second, another study in the Pokegama Creek basin documented a decrease in macroinvertebrate diversity from 1997 through 2000, driven largely by increasing proportions of chironomids (C. Chizinski, unpubl. data). Burrowing chironomids (Holker \& Stief 2005) may be unavailable as prey for the fish species in the Pokegama Creek system, which could potentially lead to increased mortality over time through chronic undernourishment. Third, total spring precipitation in 2006 and 2007 was the lowest of the study period, thus low water levels (Lake 2003) are another possible explanation for reduced fish numbers.

The fish community in the Pokegama Creek system appears to have responded to different environmental 
Relations between fish abundances, summer temperatures, and forest harvest
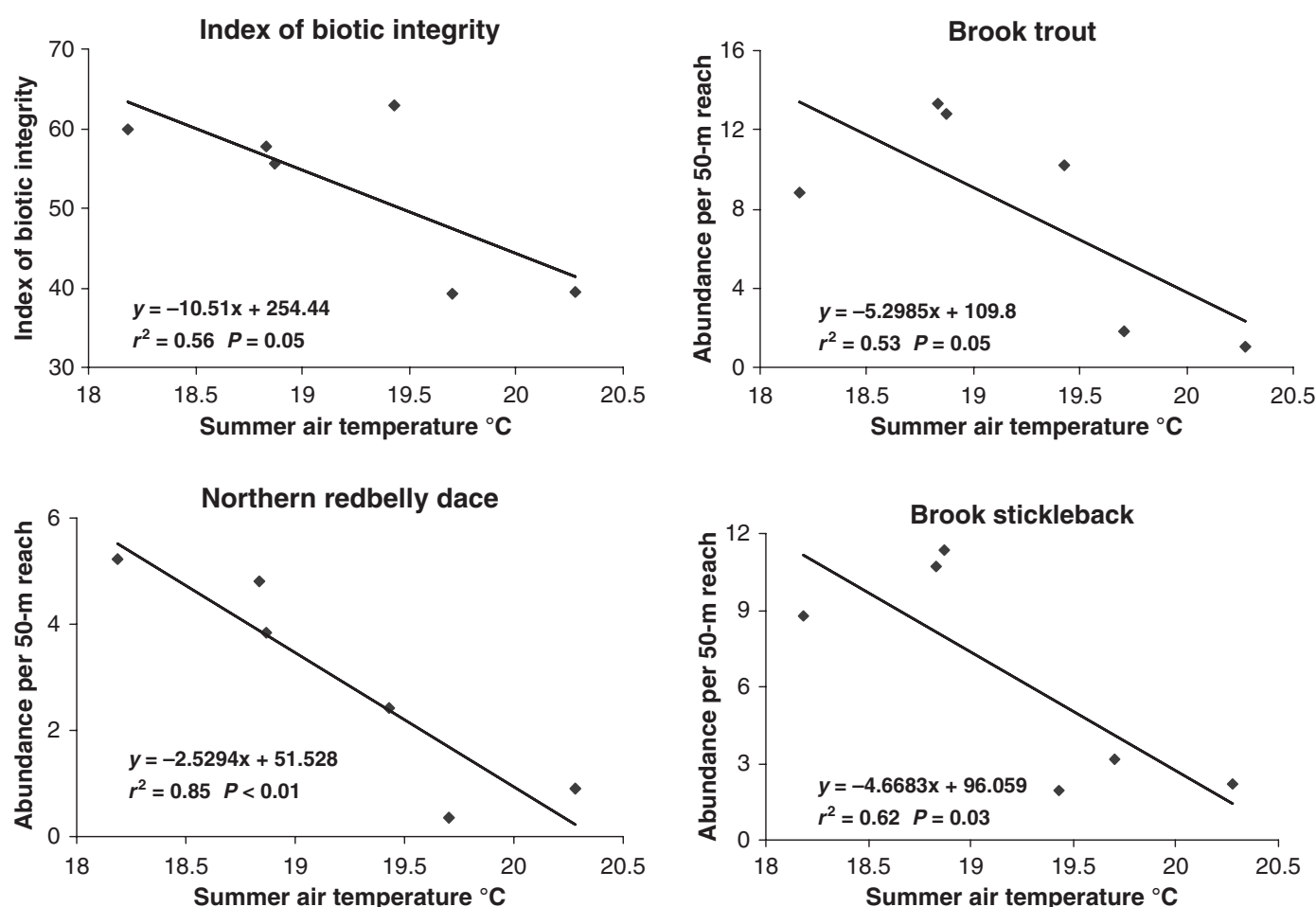

Fig. 4. The relationship between mean summer air temperature from June through August and the IBI scores and abundance (annual mean for all 50-m reaches in the basin) of brook trout, northern redbelly dace, and brook stickleback.

conditions over the study period. Prior research in the Pokegama Creek system showed a negative relationship between IBI scores and fine substrates from 1997 to 2000 (Hemstad et al. 2008). However, our analyses showed no relationship between temporal patterns in IBI scores and fine substrates at the basin scale. Our multiple regressions and univariate regressions indicate a strong connection between summer air temperatures and the fish community; warmer temperatures may favour some species at the expense of others (Baltz et al. 1982; Reeves 1985).

\section{Brook trout}

The abundance of brook trout declined consistently during the study period. The reason for the decline in brook trout is not clear, although previous research indicates changes in fine sediment (Alexander \& Hansen 1986; Waters 1995; Finstad et al. 2007) or large wood (Johnson et al. 2003) could have reduced the habitat available for brook trout and macroinvertebrates. Our study design could not rule out bottomup trophic effects as an explanation for the consistent reduction in brook trout abundance. Based on univariate regressions, the most compelling explanation for the brook trout decline is that increasing temperatures over the study period caused mortality (or emigration to the nearest coldwater stream $5 \mathrm{~km}$ south). Although the highest seven-day mean water temperatures we observed $\left(17.9^{\circ} \mathrm{C}\right.$ in 2006 and $17.4^{\circ} \mathrm{C}$ in 2007) did not reach the critical thermal maximum of $22.3{ }^{\circ} \mathrm{C}$ for brook trout (Eaton et al.

Table 4. Coefficients of determination $\left(r^{2}\right)$ for univariate regressions between $|B|$ scores or fish abundances and surficial fine substrates, summer air temperature, or total spring precipitation at the basin scale.

\begin{tabular}{|c|c|c|c|c|c|c|}
\hline & $\begin{array}{l}\text { Fine } \\
\text { substrates } \\
(\%)\end{array}$ & $P$-value & $\begin{array}{l}\text { Summer air } \\
\text { temperature } \\
\left({ }^{\circ} \mathrm{C}\right)\end{array}$ & $P$-value & $\begin{array}{l}\text { Total spring } \\
\text { precipitation } \\
(\mathrm{mm})\end{array}$ & $P$-value \\
\hline Index of biotic integrity & 0.08 & 0.59 & 0.56 & 0.05 & 0.41 & 0.17 \\
\hline Brook trout & 0.07 & 0.61 & 0.53 & 0.05 & 0.40 & 0.18 \\
\hline Northern redbelly dace & 0.07 & 0.62 & 0.85 & 0.01 & 0.05 & 0.67 \\
\hline Brook stickleback & 0.01 & 0.86 & 0.62 & 0.03 & 0.02 & 0.81 \\
\hline Creek chub & 0.10 & 0.55 & 0.05 & 0.35 & 0.32 & 0.23 \\
\hline Central mudminnow & 0.28 & 0.28 & 0.01 & 0.45 & 0.01 & 0.92 \\
\hline Finescale dace & 0.05 & 0.67 & 0.49 & 0.07 & 0.01 & 0.85 \\
\hline
\end{tabular}




\section{Merten et al.}

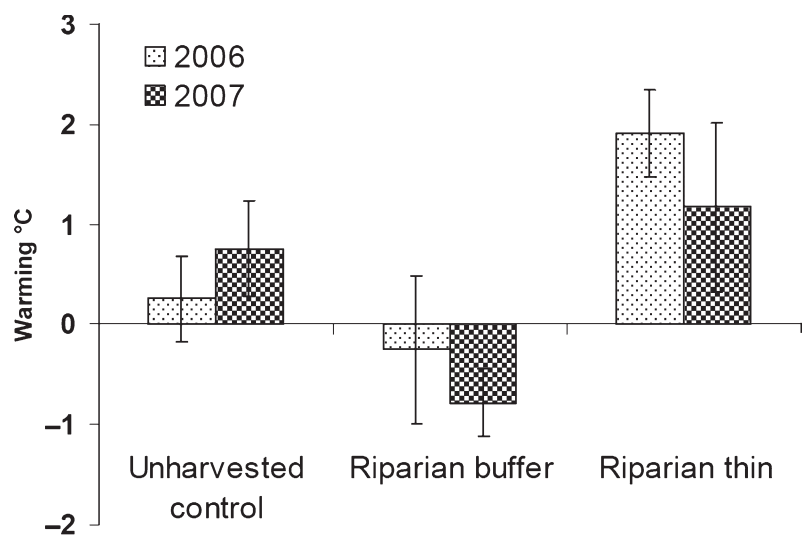

Harvest treatment

Fig. 5. Mean August temperature just downstream of each site minus the mean August temperature just upstream of each site (i.e., stream warming) by harvest treatment and year. Error bars are the standard error of the mean.

1995), sublethal thermal effects on fish can be subtle (Boughton et al. 2007). Invertebrate production may have been limited by the significantly higher levels of fine sediment following harvest (Waters 1995; Matthaei et al. 2006; Hemstad et al. 2008) or warming temperatures (Durance \& Ormerod 2007), and thus precluded fish from consuming sufficient quantities of invertebrates during warmer temperatures (Ries \& Perry 1995).

\section{Northern redbelly dace}

Abundance of northern redbelly dace decreased significantly over time. At the basin scale, higher abundances of northern redbelly dace were associated with years with colder air temperatures in summer. Stasiak (1972) noted that northern redbelly dace prefer streams with a constant flow of cool groundwater; warmer summer temperatures in our study may have caused direct mortality or emigration.

\section{Brook stickleback}

Abundance of brook sticklebacks decreased over time, although not significantly. As for brook trout and northern redbelly dace, brook stickleback abundance at the basin scale was negatively related to warmer air temperatures in summer. Brook sticklebacks require cool water (Winn 1960), but they are also sensitive to environmental degradation (Lyons 2006). As with other species, increased fine sediment after forest harvest (Hemstad et al. 2008) could have reduced invertebrate prey numbers (Waters 1995; Matthaei et al. 2006) for brook stickleback.
Creek chub

The creek chub was the only species that increased significantly over time. Contrary to previous studies, creek chub abundance was not significantly related to spring precipitation (Franssen et al. 2006) at the basin scale. The increasing temporal trend for creek chubs is not surprising, as previous studies have also documented increases in creek chub numbers after forest harvest (Jones et al. 1999; Sutherland et al. 2002). Creek chub abundance may have increased due to less predation on their eggs and fry from other species (i.e., northern redbelly dace and brook stickleback), or less competition for invertebrate prey. It is also possible that creek chubs gained a competitive advantage from warmer water temperatures, as has been documented with other pairs of species (Baltz et al. 1982; Reeves 1985). Finally, creek chubs build a clean gravel nest by exporting mouthfuls of sand and importing gravel (Ross 1977), which may have made their reproductive success more resistant to the increased levels of fine sediment following harvesting.

\section{Central mudminnow}

The abundance of central mudminnows was fairly stable for the duration of the study. Central mudminnows are eurythermal (Klinger et al. 1982), generalist feeders (Paszkowski 1984) and can use fine sediment as habitat by burrowing into the substrate (Peckham \& Dineen 1957). Central mudminnows became the most abundant species in 2006 and 2007, as most species had declined in abundance and creek chubs, though on the rise, remained relatively uncommon.

\section{Warming due to forest harvest}

Estimated stream warming was significantly greater in thinned riparian sites relative to riparian buffer sites, possibly due to patches of open canopy (Hemstad et al. 2008). Although stream warming associated with narrowed buffers has been documented in the past (Beschta et al. 1987), the current study is unusual in that we have documented warming ten years postharvest in some treatments. Removal of riparian vegetation may exacerbate the effects of warmer air temperatures by reducing shade. However, the sample size was limited for testing site-scale warming, and it is not clear why warming at unharvested control sites was not significantly different from other treatments.

\section{Conclusion}

In summary, this study demonstrated that summer air temperatures can influence temporal patterns in fish 
communities more than fine sediment or spring precipitation. Studies assessing land use impacts on fish population trends should also consider influences of interannual weather patterns and climate conditions. Ongoing climate change (Rosenzweig et al. 2008) can be more important to fish communities than direct anthropogenic effects (Daufresne \& Boet 2007), highlighting a pressing need to protect cool water temperatures (Eaton \& Scheller 1996; Pilgrim et al. 1998; Stefan et al. 2001; Chu et al. 2008). The effects of warmer temperatures on fish may be exacerbated in streams where degraded habitat prevents prey production from keeping pace with increased metabolic demands (Ries \& Perry 1995). Forest management can preserve cool water temperatures by maintaining or restoring forested buffers with sufficient overstory to fully shade the stream (Beschta et al. 1987). Based on previous literature (Salo \& Cundy 1987; Chamberlin et al. 1991), a conservative approach would be to maintain preharvest levels of leaf litter inputs, hydrologic fluctuations, large wood inputs, and fine sediment loading. In addition, practitioners restoring harvested sites should consider mitigation of warming temperatures (e.g., restoring full shade) along with other ecological processes (Muotka \& Syrjanen 2007).

\section{Acknowledgements}

This work was funded by the Minnesota Department of Natural Resources Section of Fisheries, the Minnesota Forest Resources Council, the National Council for Air and Stream Improvement, the U.S. Forest Service, Minnesota Trout Unlimited, and the Minnesota Environment and Natural Resources Trust Fund as recommended by the Legislative Citizen Commission on Minnesota Resources. Charlie Blinn and Brian Palik selected the study sites and supervised the manipulations. John Hansen and Jim Marshall of UPM-Kymenne Corporation Blandin provided access to the study sites. Forest harvest was completed by Rieger Logging. Field assistance was provided by Andy Arola, Brenda Asmus, Jason Bronk, Rebecca Bronk, Ryan Carlson, Bill Coates, Jacquelyn Conner, MaryKay Fox, Jo Fritz, Sarah Harnden, Marty Melchior, Steffen Merten, Mateya Miltich, Brittany Mitchell, Erik Mundahl, Elliot Nitzkowski, Ian Phelps, Lisa Pugh, Jeff Rice, David Schroeder, Jeremy Steil, Kevin Stroom, Dustin Wilman, and Jason Zwonitzer. The Statistical Consulting Service at the University of Minnesota provided R code for analysis. Comments from Jacques Finlay, Heinz Stefan, and four anonymous reviewers improved the quality of the manuscript.

\section{References}

Alexander, G.R. \& Hansen, E.A. 1986. Sand bed load in a brook trout stream. North American Journal of Fisheries Management 6: 9-23.

Angermeier, P.L. \& Karr, J.R. 1984. Relationships between woody debris and fish habitat in a small warmwater stream. Transactions of the American Fisheries Society 113: 716726.
Austin, J. \& Colman, S. 2008. A century of temperature variability in Lake Superior. Limnology and Oceanography 53: 2724-2730.

Baltz, D.M., Moyle, P.B. \& Knight, N.J. 1982. Competitive interactions between benthic stream fishes, riffle sculpin Cottus gulosus, and speckled dace Rhinichthyes osculus. Canadian Journal of Fisheries and Aquatic Sciences 39: 1502-1511.

Beechie, T.J. \& Sibley, T.H. 1997. Relationships between channel characteristics, woody debris, and fish habitat in northwestern Washington streams. Transactions of the American Fisheries Society 126: 217-229.

Beschta, R.L., Bilby, R.E., Brown, G.W., Holby, L.B. \& Hofstra, T.D. 1987. Stream temperature and aquatic habitat: fisheries and forestry interactions. In: Salo, E.O. \& Cundy, T.W., eds Streamside management: forestry-fishery interactions. Seattle, WA: Institute of Forest Resources, University of Washington, pp. 191-232.

Bojsen, B.H. \& Barriga, R. 2002. Effects of deforestation on fish community structure in Ecuadorian Amazon streams. Freshwater Biology 47: 2246-2260.

Borg, D., Rutherford, I. \& Stewardson, M. 2007. The geomorphic and ecological effectiveness of habitat rehabilitation works: continuous measurement of scour and fill around large logs in sand-bed streams. Geomorphology 89: 205-216.

Boughton, D.A., Gibson, M., Yedor, R. \& Kelley, E. 2007. Stream temperature and the potential growth and survival of juvenile Oncorhynchus mykiss in a southern California creek. Freshwater Biology 52: 1353-1364.

Broadmeadow, S. \& Nisbet, T.R. 2004. The effects of riparian forest management on the freshwater environment: a literature review of best management practice. Hydrology and Earth System Sciences 8: 286-305.

Brown, G.W. 1970. Predicting the effect of clearcutting on stream temperature. Journal of Soil and Water Conservation 25: 11-13.

Chamberlin, T.W., Harr, R.D. \& Everest, F.H. 1991. Timber harvesting, silviculture, and watershed processes. In: Meehan, W.R., ed. Influences of Forest and Rangeland Management on Salmonid Fisheries and Their Habitats. Bethesda, MD: American Fisheries Society, pp. 181-206.

Chu, C., Jones, N.E., Mandrak, N.E., Piggott, A.R. \& Minns, C.K. 2008. The influence of air temperature, groundwater discharge, and climate change on the thermal diversity of stream fishes in southern Ontario watersheds. Canadian Journal of Fisheries and Aquatic Science 65: 297-308.

Crook, D.A. \& Robertson, A.I. 1999. Relationships between riverine fish and woody debris: implications for lowland rivers. Marine \& Freshwater Research 50: 941-953.

Daufresne, M. \& Boet, P. 2007. Climate change impacts on structure and diversity of fish communities in rivers. Global Change Biology 13: 2467-2478.

Davies, P.E., McIntosh, P.D., Wapstra, M., Bunce, S.E., Cook, L.S., French, B. \& Munks, S.A. 2005. Changes to headwater stream morphology, habitats and riparian vegetation recorded 15 years after pre-Forest Practices Code forest clearfelling in upland granite terrain, Tasmania, Australia. Forest Ecology and Management 217: 331-350.

DeGroot, J.D., Hinch, S.G. \& Richardson, J.S. 2007. Effects of logging second-growth forests on headwater populations of coastal cutthroat trout: a 6-year, multi-stream, before-and- 


\section{Merten et al.}

after field experiment. Transactions of the American Fisheries Society 136: 211-226.

Durance, I. \& Ormerod, S.J. 2007. Climate change effects on upland stream macroinvertebrates over a 25-year period. Global Change Biology 13: 942-957.

Eaton, J.G. \& Scheller, R.M. 1996. Effects of climate warming on fish thermal habitat in streams of the United States. Limnology and Oceanography 41: 1109-1115.

Eaton, J.G., McCormick, J.H., Goodno, B.E., O’Brien, D.G., Stefan, H.G., Hondzo, M. \& Scheller, R.M. 1995. A field information-based system for estimating fish temperature tolerances. Fisheries 20: 10-18.

Ehrman, T.P. \& Lamberti, G.A. 1992. Hydraulic and particulate matter retention in a 3rd-order Indiana stream. Journal of the North American Benthological Society 11: 341-349.

Fausch, K.D., Torgerson, C.E., Baxter, C.V. \& Li, H.W. 2002. Landscapes to riverscapes: bridging the gap between research and conservation of stream fishes. BioScience 52: 483-498.

Finstad, A.G., Einum, S., Forseth, T. \& Ugedal, O. 2007. Shelter availability affects behaviour, size-dependent and mean growth of juvenile Atlantic salmon. Freshwater Biology 52: 1710-1718.

Franssen, N.R., Gido, K.B., Guy, C.S., Tripe, J.A., Shrank, S.J., Strakosh, T.R., Bertrand, K.N., Franssen, C.M., Pitts, K.L. \& Paukert, C.P. 2006. Effects of floods on fish assemblages in an intermittent prairie stream. Freshwater Biology 51: 20722086.

Hall, J.D. \& Lantz, R.L. 1969. Effects of logging on the habitat of coho salmon and cutthroat trout in coastal streams. In: Northcote, T.G., ed Symposium on salmon and trout in streams. Vancouver, BC: H.R. MacMillan Lectures in Fisheries, Institute of Fisheries, University of British Columbia, pp. 355-375.

Hemstad, N.A. \& Newman, R.M. 2006. Local and landscape effects of past forest harvest on stream habitat and fish assemblages. In: Hughes, R.M., Wang, L. \& Seelbach, P.W., eds Influences of landscape on stream habitat and biological assemblages. Bethesda, MD: American Fisheries Society, pp. 413-427.

Hemstad, N.A., Merten, E.C. \& Newman, R.M. 2008. Effects of riparian forest thinning by two types of mechanical harvest on stream fish and habitat in northern Minnesota. Canadian Journal of Forest Research 38: 247-256.

Holker, F. \& Stief, P. 2005. Adaptive behavior of chironomid larvae (Chironomus riparius) in response to chemical stimuli from predators and resource density. Behavioral Ecology and Sociobiology 58: 256-263.

Ihaka, R. \& Gentleman, R. 1996. R: a language for data analysis and graphics. Journal of Computational and Graphical Statistics 5: 299-314.

Johnson, L.B., Breneman, D.H. \& Richards, C. 2003. Macroinvertebrate community structure and function associated with large wood in low gradient streams. River Research and Applications 19: 199-218.

Jones, E.B., Helfman, G.S., Harper, J.O. \& Bolstad, P.V. 1999. Effects of riparian forest removal on fish assemblages in southern Appalachian streams. Conservation Biology 13: 1454-1465.
Kedzierski, W.M. \& Smock, L.A. 2001. Effects of logging on macroinvertebrate production in a sand-bottomed, lowgradient stream. Freshwater Biology 46: 821-833.

Kiffney, P.M., Richardson, J.S. \& Bull, J.P. 2003. Responses of periphyton and insects to experimental manipulation of riparian buffer width along forest streams. Journal of Applied Ecology 40: 1060-1076.

Klinger, S.A., Magnuson, J.J. \& Gallepp, G.W. 1982. Survival mechanisms of the central mudminnow (Umbra limi), fathead minnow (Pimephales promelas) and brook stickleback $(\mathrm{Cu}$ laea inconstans) for low oxygen in winter. Environmental Biology of Fishes 7: 113-120.

Kreutzweiser, D.P., Capell, S.S. \& Beall, F.D. 2004. Effects of selective forest harvesting on organic matter inputs and accumulation in headwater streams. Northern Journal of Applied Forestry 21: 19-30.

Kwak, T.J. 1992. Modular microcomputer software to estimate fish population parameters, production rates and associated variance. Ecology of Freshwater Fish 1: 73-75.

Lake, P.S. 2003. Ecological effects of perturbation by drought in flowing waters. Freshwater Biology 48: 1161-1172.

Larranaga, S., Diez, J.R., Elosegi, A. \& Pozo, J. 2003. Leaf retention in streams of the Aguera basin (northern Spain). Aquatic Sciences - Research Across Boundaries 65: 158166.

Lyons, J. 2006. A fish-based index of biotic integrity to assess intermittent headwater streams in Wisconsin, USA. Environmental Monitoring and Assessment 122: 239-258.

Macdonald, J.S., Beaudry, P.G., MacIsaac, E.A. \& Herunter, H.E. 2003. The effects of forest harvesting and best management practices on streamflow and suspended sediment concentrations during snowmelt in headwater streams in sub-boreal forests of British Columbia, Canada. Canadian Journal of Forest Research 33: 1397-1407.

Martel, N., Rodriguez, M.A. \& Berube, P. 2007. Multi-scale analysis of responses of stream macrobenthos to forestry activities and environmental context. Freshwater Biology 52: 85-97.

Matthaei, C.D., Weller, F., Kelly, D.W. \& Townsend, C.R. 2006. Impacts of fine sediment addition to tussock, pasture, dairy and deer farming streams in New Zealand. Freshwater Biology 51: 2154-2172.

Moore, R.D. \& Wondzell, S.M. 2005. Physical hydrology and the effects of forest harvesting in the Pacific Northwest: a review. Journal of the American Water Resources Association 41: 763-784.

Mundahl, N.D. \& Simon, T.P. 1999. Development and application of an index of biotic integrity for coldwater streams of the upper Midwestern United States. In: Simon, T.P., ed. Assessing the sustainability and biological integrity of water resources using fish communities. Boca Raton, FL: CRC Press, pp. 383-415.

Muotka, T. \& Syrjanen, J. 2007. Changes in habitat structure, benthic invertebrate diversity, trout populations and ecosystem processes in restored forest streams: a boreal perspective. Freshwater Biology 52: 724-737.

Murphy, M.L. \& Koski, K.V. 1989. Input and depletion of woody debris in Alaska streams and implications for streamside management. North American Journal of Fisheries Management 9: 427-436. 
Nislow, K.H. \& Lowe, W.H. 2006. Influences of logging history and riparian forest characteristics on macroinvertebrates and brook trout (Salvelinus fontinalis) in headwater streams. Freshwater Biology 51: 388-397.

Oelbermann, M. \& Gordon, A.M. 2000. Quantity and quality of autumnal litterfall into a rehabilitated agricultural stream. Journal of Environmental Quality 29: 603-611.

Palik, B.J., Zasada, C. \& Hedman, C.W. 2000. Ecological principles for riparian silviculture. In: Verry, E.S., Hornbeck, J.W. \& Dolloff, C.A., eds Riparian management in forests of the Continental Eastern United States. Boca Raton, FL: Lewis Publishers, pp. 233-254.

Palik, B., Cease, K. \& Egeland, L. 2003. Aspen regeneration in riparian management zones in northern Minnesota: effects of residual overstory and harvest method. Northern Journal of Applied Forestry 20: 79-84.

Paszkowski, C.A. 1984. The foraging behavior of a generalist feeder, the central mudminnow (Umbra limi). Canadian Journal of Zoology 62: 457-462.

Peckham, R.S. \& Dineen, C.F. 1957. Ecology of the central midminnow, Umbra limi (Kirtland). American Midland Naturalist 58: 222-231.

Pilgrim, J.M., Fang, X. \& Stefan, H.G. 1998. Stream temperature correlations with air temperatures in Minnesota: implications for climate warming. Journal of the American Water Resources Association 34: 1109-1121.

Poff, N.L. \& Allen, J.D. 1995. Functional organization of stream fish assemblages in relation to hydrological variability. Ecology 76: 606-627.

Quinn, J.M., Phillips, N.R. \& Parkyn, S.M. 2007. Factors influencing retention of coarse particulate organic matter in streams. Earth Surface Processes and Landforms 32: 11861203.

Quist, M.C. \& Guy, C.S. 2001. Growth and mortality of prairie stream fishes: relations with fish community and instream habitat characteristics. Ecology of Freshwater Fish 10: 88-96.

Reeves, G.H. 1985. Interactions between the redside shiner (Richardsonius balteatus) and the steelhead trout (Salmo gairdneri) in western Oregon: the influence of water temperature. Canadian Journal of Fisheries and Aquatic Sciences 44: 1603-1613.

Ries, R.D. \& Perry, S.A. 1995. Potential effects of global climate warming on brook trout growth and prey consumption in central Appalachian streams, USA. Climate Research 5: 197-206.
Rosenzweig, C., Karoly, D., Vicarelli, M., Neofotis, P., Wu, Q., Casassa, G., Menzel, A., Root, T.L., Estrella, N., Seguin, B., Tryjanowski, P., Liu, C., Rawlins, S. \& Imeson, A. 2008. Attributing physical and biological impacts to anthropogenic climate change. Nature 453: 353-358.

Ross, M.R. 1977. Function of creek chub (Semotilus atromaculatus) nest-building. Ohio Journal of Science 77: 36-37.

Salo, E.O. \& Cundy, T.W. 1987. Streamside management: forestry-fishery interactions. Seattle, WA: Institute of Forest Resources, University of Washington, $471 \mathrm{pp}$.

Serengil, Y., Gokbulak, F., Ozhan, S., Hizal, A., Sengonul, K., Balci, A.N. \& Ozyuvaci, N. 2007a. Hydrological impacts of a slight thinning treatment in a deciduous forest ecosystem in Turkey. Journal of Hydrology 333: 569-577.

Serengil, Y., Gokbulak, F., Ozhan, S., Hizal, A. \& Sengonul, K. 2007b. Alteration of stream nutrient discharge with increased sedimentation due to thinning of a deciduous forest in Istanbul. Forest Ecology and Management 246: 264-272.

Stasiak, R.H. 1972. The morphology and life history of the finescale dace, Pfrille neogaea, in Itasca State Park, Minnesota. PhD Thesis, Minneapolis: University of Minnesota.

Stefan, H.G., Fang, X. \& Eaton, J.G. 2001. Simulated fish habitat changes in North American lakes in response to projected climate warming. Transactions of the American Fisheries Society 130: 459-477.

Sutherland, A.B., Meyer, J.L. \& Gardiner, E.P. 2002. Effects of land cover on sediment regime and fish assemblage structure in four southern Appalachian streams. Freshwater Biology 47: 1791-1805.

Verry, E.S. 1986. Forest harvesting and water: the Lake States experience. Water Resources Bulletin 22: 1039-1047.

Waters, T.F. 1995. Sediment in streams: sources, biological effects and control. Bethesda, MD: American Fisheries Society, $251 \mathrm{pp}$.

Weatherley, N.S. \& Ormerod, S.J. 1990. Forests and the temperature of upland streams in Wales: a modeling exploration of the biological effects. Freshwater Biology 24: 109-122.

Weisberg, S. 1985. Applied linear regression. New York, NY: John Wiley \& Sons, 324 pp.

Williams, L.R., Taylor, C.M., Warren, M.L. \& Clingenpeel, J.A. 2002. Large-scale effects of timber harvesting on stream systems in the Ouachita Mountains, Arkansas, USA. Environmental Management 29: 76-87.

Winn, H.E. 1960. Biology of the brook stickleback Eucalia inconstans (Kirtland). American Midland Naturalist 63: 424438. 